\title{
Tingkat Stress Akademik Mahasiswa dalam Pembelajaran Daring pada Periode Pandemi Covid-19
}

\author{
Author(s): Iqtina Sabnaha Oktariani, Rahmi Sofah, \& Rani Mega Putri \\ Editor: Anastasia Dewi Anggraeni \\ Publication details, including author guidelines \\ URL: https://jlis.idcounselor.com/index.php/jlis/about/submissions
}

\author{
Article History \\ Received: $1 / 14 / 2021$ \\ Revised: 3/20/2021 \\ Accepted: 4/8/2021
}

How to cite this article (APA)

Oktariani, I. S., Sofah, R., \& Putri, R. M. (2021). Tingkat Stress Akademik Mahasiswa dalam Pembelajaran Daring pada Periode Pandemi Covid-19. Journal of Learning and Instructional Studies, 1(1), 17-24.

https://doi.org/10.46637/jlis.v1i1.3

The readers can link to article via https://doi.org/10.46637/jlis.v1i1.3

\section{SCROLL DOWN TO READ THIS ARTICLE}

\begin{abstract}
Southeast Asia Mental Health and Counseling Association (as publisher) makes every effort to ensure the accuracy of all the information (the "Content") contained in the publications. However, we make no representations or warranties whatsoever as to the accuracy, completeness, or suitability for any purpose of the Content. Any opinions and views expressed in this publication are the opinions and views of the authors and are not the views of or endorsed by Southeast Asia Mental Health and Counseling Association. The accuracy of the Content should not be relied upon and should be independently verified with primary sources of information. Southeast Asia Mental Health and Counseling Association shall not be liable for any losses, actions, claims, proceedings, demands, costs, expenses, damages, and other liabilities whatsoever or howsoever caused arising directly or indirectly in connection with, in relation to, or arising out of the use of the content.
\end{abstract}

Journal of Learning and Instructional Studies is published by Southeast Asia Mental Health and Counseling Association comply with the Principles of Transparency and Best Practice in Scholarly Publishing at all stages of the publication process. Journal of Learning and Instructional Studies also may contain links to web sites operated by other parties. These links are provided purely for educational purpose.

\section{(c) (i)}

This work is licensed under a Creative Commons Attribution 4.0 International License.

Copyright by Oktariani, et al (2021)

The author(s) whose names are listed in this manuscript declared that they have NO affiliations with or involvement in any organization or entity with any financial interest (such as honoraria; educational grants; participation in speakers' bureaus; membership, employment, consultancies, stock ownership, or other equity interest; and expert testimony or patent-licensing arrangements), or non-financial interest (such as personal or professional relationships, affiliations, knowledge or beliefs) in the subject matter or materials discussed in this manuscript. This statement is signed by all the authors to indicate agreement that the all information in this article is true and correct. 


\title{
Tingkat Stress Akademik Mahasiswa dalam Pembelajaran Daring pada Periode Pandemi Covid-19
}

\author{
Iqtina Sabnaha Oktariani, Rahmi Sofah, \& Rani Mega Putri* \\ Universitas Sriwijaya, Palembang, Indonesia.
}

\begin{abstract}
Academic institutions, both from the primary education level to higher education, have been temporarily closed due to the spread of the Corona Virus 2019 (Covid-19). The purpose of this study was to determine the level of academic stress during online learning in the Guidance and Counseling Study Program at Sriwijaya University. Seventy guidance and counseling students were involved in this study. We used Academic Stress questionnaires during online learning to collect data and disseminate it via google form and analyzed descriptively quantitatively. The results of the study showed that the Academic stress of guidance and counseling students of FKIP Sriwijaya University was in the high category $15.71 \%$, the medium category $65.71 \%$, and the low category $18.57 \%$. Referring to the findings of this study, it can be concluded that the Palembang-Indralaya Class Guidance and Counseling students class 2018, 2019, 2020 experience moderate academic stress.
\end{abstract}

Key Words: Academic Stress; Online Learning; Covid-19; University

Abstrak: Institusi pendidikan baik itu dari tingkat pendidikan dasar hingga perguruan tinggi terpaksa ditutup untuk sementara waktu karena penyebaran Corona Virus 2019 (Covid-19). Tujuan penelitian ini untuk mengetahui tingkat stress akademik mahasiswa selama pembelajaran daring pada Program Studi Bimbingan dan Konseling di Universitas Sriwijaya. Tujuh puuh orang mahasiswa bimbingan dan konseling dilibatkan dalam studi ini. Kami menggunakan menggunakan angket Stress Akademik selama pembelajaran daring untuk mengumpulkan data dan penyebarannya melalui google form serta dianalisis secara deskriptif kuantitatif. Hasil dari penelitian menunjukkan bahwa stress Akademik mahasiswa bimbingan dan Konseling FKIP Universitas Sriwijaya berada pada kategori tinggi 15,71\%, kategori sedang 65,71\%, dan kategori rendah 18,57\%. Mengacu temuan penelitian ini, dapat disimpulkan bahwa mahasiswa Bimbingan dan Konseling Kelas PalembangIndralaya angkatan 2018, 2019, 2020 mengalami stress akademik dengan kategori sedang.

Kata Kunci: Stres akademik; Belajar dalam jaringan; Covid-19; Universitas

\footnotetext{
* Corresponding author: Rani Mega Putri. Universitas Sriwijaya. JI. Masjid Al Gazali, Bukit Lama, Kec. Ilir Bar. I, Kota Palembang, Sumatera Selatan 30128, Indonesia. Email: rani@konselor.org
} 


\section{Pendahuluan}

Penyebaran virus corona pertama kali terjadi di kota Wuhan (China) pada akhir tahun 2019 yang membuat masyarakat menjadi panik dan khawatir. Penyebaran virus ini sangat cepat dan menyebar ke seluruh negara di dunia. Virus ini masuk ke Indonesia dengan sangat cepat dan menular dalam kurun waktu yang singkat. Untuk melakukan pencegahan Covid-19 pemerintah Indonesia menerapkan Social Distancing serta physical distancing dengan tidak melakukan aktivitas di luar rumah. Pemerintah mengeluarkan Surat Edaran yang mendorong seluruh aktivitas pembelajaran dilakukan di rumah dan bekerja dari rumah. Institusi pendidikan baik itu dari tingkat prasekolah hingga perguruan tinggi ditutup untuk sementara waktu. Aktivitas pembelajaran semuanya dilakukan secara jarak jauh atau dalam jaringan (Daring). Selama pembelajaran dialihkan secara daring, mahasiswa dituntut untuk harus serba bisa dalam menyesuaikan diri selama pembelajaran daring, yang mana mahasiswa harus bisa cepat, tanggap dalam mengikuti proses pembelajaran yang dilakukan secara daring dengan memanfaatkan berbagai flatform pembelajaran (Rosali, 2020).

Pembelajaran secara daring diimplementasikan dengan beragam cara oleh pendidik di tengah penutupan kampus, termasuk pada kampus Universitas Sriwijaya. Namun implementasi tersebut dinilai tidak maksimal dan bahkan menunjukkan masih ada ketidakpastian di kalangan pendidik untuk beradaptasi di iklim digital. Penugasan kepada mahasiswa dilakukan melalui berbagai cara, diantaranya dengan memanfaatkan Whatsapp Group, Google Classroom, Telegram, maupun Moodle. Tidak dapat dipungkiri bahwa akan terjadi juga beberapa hambatan pada mahasiswa selama proses perkuliahan berlangsung yang dilakukan secara daring. Hmbatan tersebut diantaranya terkendala akibat sinyal, kuota internet menjadi boros, adanya perkerjaan rumah yang harus dikerjakan, kurangnya pemahaman dalam menggunakan flatform pembelajaran, serta tugas kuliah yang menumpuk untuk segera diselesaikan dan kurangnya pemahaman terhadap materi yang dijelaskan oleh dosen (Anugrahana, 2020; Pawicara \& Conilie, 2020). Berbagai macam hambatan yang terjadi selama proses perkuliahan dialihkan secara daring tentu akan menimbulkan kecemasan pada Mahasiswa yang dapat mempengaruhi hasil belajar mahasiswa. Karna kecemasan cenderung menghasilkan kebingungan dan distorsi persepsi. Distorsi tersebut tentu akan menganggu proses pembelajaran dengan menurunkan kemampuan dalam memusatkan perhatian (Fauzi et al., 2020).

Cemas berkepanjangan yang terjadi secara terus menerus tentu akan menyebabkan stress yang dapat menganggu aktivitas sehari-hari mahasiswa. Stress Akademik terjadi disebabkan oleh adanya academic stressor (Barseli et al., 2020), salah satu penyebab terjadinya pemicu stress yang bermula dari suatu proses pembelajaran seperti adanya suatu tekanan untuk mendapatkan nilai yang baik seperti Indeks Prestasi Kumulatif (IPK), lamanya belajar, banyaknya ragam tugas yang harus dikerjakan, adanya rasa cemas dalam menghadapi ujian tengah semester, ujian akhir semester, mendapatkan nilai yang kurang memuaskan, adapatasi dengan keadaan baru atau sistem belajar yang baru. Beberapa studi (Hasanah et al., 2020; Yuwono, 2020a) mengkonfirmasi bahwa sebagian besar mahasiswa memiliki rentang stress berat dikarenakan pengaruh manajemen waktu yang kurang baik. Sebagian mahasiswa mengalami stress sangat berat karena tidak memiliki kemampuan memajemen diri sehingga menimbulkan beberapa keluhan dari fisik, perilaku maupun Fisiologis seperti mudah sakit, pusing, melakukan penundaan penyelesaian tugas dan adanya gangguan tidur (Barseli et al., 2020; Sekar et al., 2020). Cemas berkepanjangan dan terjadi secara terus menerus tentu dapat menyebabkan stress yang dapat menggangu aktivitas sehari-hari. Adanya tanggung jawab dan tuntutan kehidupan akademik pada mahasiswa tentu dapat menjadi bagian dari stress yang dialami oleh mahasiswa.

Journal of Learning and Instructional Studies (2021), 1(1), 17-24

https://doi.org/10.46637/jlis.v1i1.3 
Stress merupakan salah satu reaksi atau suatu respon psikologis manusia agar dihadapkan pada hal yang dirasa telah melampaui batas atau dianggap sulit untuk dihadapi. Akibat dari adanya tuntutan akademik yang banyak, terjadilah stress akademik yang disebabkan oleh adanya academic stressor (Soto-Rubio et al., 2020; Yuwono, 2020b). Academic stressor adalah salah satu penyebab pemicu stress yang bermula dari suatu proses pembelajaran seperti pengaturan waktu yang berantakan, manajemen diri yang kurang tepat, adanya gangguan hubungan interpersonal, dan adanya konflik dengan teman, dosen, pacar maupun keluarga.

Stress adalah salah satu reaksi atau suatu respon psikologis individu saat dihadapkan pada suatu hal-hal yang dirasa telah melampaui batas atau dianggap sulit untuk dilewati dan dihadapi (Hasanah et al., 2020). Pada hakikatnya, kata stress merujuk pada sebuah keadaan atau kondisi seseorang yang sedang mengalami tuntutan emosi yang berlebihan dan adanya suatu keadaan yang dapat mengakibatkan munculnya suatu gejala, seperti depresi, adanya kelelahan kronis yang dialami, mudah emosi, marah, dan selalu gelisah (Sagita et al., 2017). Stress juga merupakan suatu respon dari individu terhadap suatu kejadian yang dapat memicu timbulnya stress yang tidak dapat dihadapi oleh individu tersebut (Jam et al., 2011). Selain itu juga stress merupakan suatu hubungan antara individu dengan lingkungan yang dinilai oleh individu tersebut sebagai suatu hal yang dapat membebani dirinya dan tentunya sangat melampaui kemampuan seseorang individu tersebut. American Accreditation Health Care Commission menyatakan definisi tentang stress adalah sebagai suatu bentuk respon terhadap situasi atau faktor yang dapat menimbulkan suatu emosi negatif atau adanya perubahan fisik dan terjadinya kombinasi dari perubahan fisik dan emosi (Agustiningsih, 2019). Stress juga sering kali muncul karena adanya suatu tekanan yang menunjukkan adanya suatu persaingan akademik yang semakin meningkat yang dapat disebut sebagai stress Akademik (Barseli et al., 2020).

Stress akademik merupakan suatu persepsi subjektif terhadap suatu kondisi akademik atau respon yang dialami mahasiswa berupa reaksi fisk, reaksi perilaku, pikiran dan emosi negatif yang muncul akibat adanya suatu tuntutan perkuliahan atau akademik. Stress akademik dapat terjadi karena adanya suatu tuntutan akademik, kesulitan dalam mengimbangi tuntutan akademik dan gagal untuk berprestasi (Boyraz \& Legros, 2020). Stress akademik adalah suatu kondisi yang sulit dihadapi oleh seorang individu dan terjadi baik itu di lingkungan sekolah maupun pendidikan. Stress akademik adalah suatu persepsi yang dimiliki oleh seseorang terhadap stressor akademik dan bagaimana mereka memberikan reaksi terhadap stressor tersebut yang terdiri dari beberapa reaksi diantaranya reaksi fisik, emosi, perilaku dan kognitif (Kountul et al., 2019; Moh, 2020). Stress akademik adalah suatu kondisi yang berhubungan dengan aspek pembelajaran, khususnya pada pengalaman belajar yang dimiliki oleh individu. Menurut Fink (Harahap et al., 2020) terdapat dua faktor yang dapat mempengaruhi terjadinya stress akademik yaitu Faktor Biologis dan Lingkungan.

Rasmun (Hutagalung, 2019; Ifdil \& Ardi, 2013; Sekar et al., 2020), menyatakan bahwa stress terbagi menjadi tiga tingkatan yakni 1) Stress ringan, yakni pada tahap ini stress sering kali terjadi dalam kehidupan seorang individu dan stress pada tahap ini hanya berlangsung dalam beberapa jam saja. Selain itu juga stress ringan ini tidak berpengaruh terhadap aspek fisiologis yang dimiliki oleh individu. Stress ringan juga biasanya hanya dirasakan oleh setiap individu, contohnya seperti mudah lupa (menurunnya daya ingat), ketiduran, atau dikritik. Dalam tahap ini juga situasi ini tidak akan menimbulkan suatu penyakit, apabila tidak terjadi secara terus-menerus; 2) Stress sedang, yakni pada tahap ini biasanya stress dapat terjadi lebih lama dibandingkan dengan stress ringan. Stress ini tentu sudah berdampak pada fisik individu dan psikologisnya. Misalnya seperti adanya kesepakatan yang belum selesai, memiliki beban kerja yang berlebihan, atau ada anggota keluarga yang 
pergi dalam jangka waktu yang lama; 3) Stress berat, yakni sering disebut sebagai stress kronis yang tentunya dapat terjadi dalam beberapa minggu sampai beberapa tahun. Misalnya stressor yang dapat menimbulkan stress berat yakni adanya hubungan yang kurang harmonis, kesulitan dalam hal finansial, dan adanya penyakit fisik yang lama.

Pada saat mengalami gejala-gejala terjadi stress sering kali terjadi tanpa disadari dikarenakan perjalanan awal terjadinya stress timbul secara lambat. Stress akan bisa dirasakan saat tahapan gejala sudah lanjut dan tentunya akan dapat mengganggu dan menghambat di lingkungan tempat individu melakukan aktivitas khsusnya dalam proses belajar mengajar. Pembelajaran merupakan suatu aktivitas untuk menyampaikan sebuah informasi dari pengajar kepada pelajar. Pembelajaran merupakan sesuatu yang dapat memberikan informasi dan ilmu pengetahuan dalam suatu interaksi yang berlangsung antara pendidik dengan pelajar (mahasiswa). Pembelajaran adalah suatu bentuk pemberian pembelajaran kepada mahasiswa dengan menggunakan suatu asas didalam pendidikan maupun menggunakan teori belajar sebagai bentuk penentu keberhasilan dalam pendidikan.

Pembelajaran daring sudah sangat dikenal dikalangan masyarakat pada umumnya dengan istilah pembelajaran online (online learning). Istilah lain pembelajaran daring ini juga disebut sebagai pembelajaran jarak jauh. Pembelajaran daring adalah suatu pembelajaran yang berlangsung dengan menggunakan sistem jaringan dimana ada interaksi antara pengajar dan yang akan diajar dengan melalui sistem tidak tatap muka secara langsung melainkan menggunakan media Isman. pembelajaran daring (learning) dapat dipahami sebagai salah satu bentuk pendidikan formal yang diselenggarakan oleh pihak kampus maupun sekolah yang mana pendidik dan pelajarnya berada di tempat lokasi yang terpisah sehingga memerlukan sistem telekomunikasi interaktif agar bisa menghubungkan keduanya dan terdapat berbagai sumber daya yang diperlukan didalamnya.

Pembelajaran daring adalah suatu media pembelajaran yang mampu mempertemukan mahasiswa dengan dosen untuk melakukan interaksi dalam pembelajaran dengan bantuan media internet (Indrayana \& Sadikin, 2020; Sadikin \& Hamidah, 2020). Beberapa cara dalam pelaksanaan pembelajaran daring dengan memerlukan suatu dukungan perangkat-perangkat mobile seperti smartphone (android), laptop, komputer, tablet, serta iphone yang dapat dipergunakan untuk bisa mengakses informasi dimana saja dan dapat dilakukan kapan saja. Dengan adanya pembelajaran daring tentu dapat mendorong mahasiswa untuk dapat memperoleh hal-hal baru dalam proses belajar, seperti dalam teknik interaksi dalam proses pembelajaran serta dapat menggunakan berbagai media pembelajaran yang memiliki beraneka ragam. Dan mahasiswa tentu dapat secara otomatis bukan hanya mendapatkan materi yang diberikan oleh dosen, malainkan mahasiswa tentu akan bisa mempelajari cara penggunaan media pembelajaran itu sendiri. Dengan menggunakan sistem pembelajaran secara daring ini tentu akan menimbulkan berbagai kendala atau masalah yang akan dihadapi baik itu mahasiswa maupun pihak dosen, misalnya materi pembelajaran yang sebelumnya belum selesai disampaikan kemudian pendidik menganti dengan tugas yang lain, dan terjadinya keluhan-keluhan pada mahasiswa karna terlalu banyaknya tugas yang harus segera diselesaikan. Kendala lain yang tentunya dapat terjadi yakni semua sistem pembelajaran daring pasti tidaklah berjalan mulus-mulus saja melainkan pasti akan mengalami kendala dalam jaringan internet dan bahkan susah untuk mengakses internet didaerah plosok, masih terbatasnya yang memiliki laptop atau komputer, banyaknya tugas yang diberikan, kurang memahami materi yang dijelaskan, memiliki penyesuaian yang kurang baik terhadap pembelajaran daring.

Dampak yang akan terjadi dalam penerapan sistem pembelajaran daring. Pada saat pandemi Covid-19 Ini para dosen dan mahasiswa tentu harus melakukan seluruh sistem pembelajaran untuk dialihkan semuanya dirumah. mahasiswa yang memiliki fasilitas internet

Journal of Learning and Instructional Studies (2021), 1(1), 17-24

https://doi.org/10.46637/jlis.v1i1.3 
maupun perangkat yang kurang memadai tapi memiliki pengetahuan yang baik justru mendapatkan nilai yang rendah dibandingkan dengan mahasiswa yang memiliki fasilitas internet dan perangkat yang mendukung tapi memiliki pengetahuan biasa-biasa saja justru mendapatkan nilai yang baik. Hal ini justru dapat memicu patahnya semangat mahasiswa yang bisa dan mampu untuk menguasai banyak keterampilan ditahun ini tetapi justru tidak memperoleh penilaian yang semestinya karna kurang dukungan internet dan perangkat yang memadai. Stress akademik tentu dapat terjadi bagi setiap mahasiswa selama pembelajaran dialihkan secara daring di tengah pandemi Covid-19.

Berdasarkan berbagai literatur yang mengenai penyebab sress akademik pada mahasiswa, maka dari itu penelitian ini juga ingin melihat tingkat stress akademik mahasiswa selama pembelajaran daring di periode pandemi Covid-19. Pengelolaan stress yang baik, sangat penting dimiliki oleh setiap mahasiswa Bimbingan dan Konseling dikarenakan agar bisa menghadapi tuntutan-tuntutan selama pembelajaran daring ditengah pandemi Covid-19 dengan baik dan agar tidak terjadi stress pada mahasiswa Bimbingan dan Konseling di Universitas Sriwijaya pada periode Pandemi Covid-19.

\section{MetOde}

Penelitian ini melibatkan 70 mahasiswa Bimbingan dan Konseling yang diambil secara random sampling. Di dalam penelitian ini peneliti menggunakan kuesioner untuk mendapatkan data penelitian. Kuesioner adalah suatu teknik pengumpulan data yang efisien yang bertujuan agar peneliti bisa mengetahui pasti variabel yang akan diukur dan tahu apa dengan pasti variabel yang akan diukur dan tau apa yang bisa diharapkan dari responden (Sugiyono, 2014). Maka dari itu peneliti menggunakan teknik pengumpulan data menggunakan Kuesioner (Angket) mengenai stress akademik. Teknik analisis data deskriptif ialah teknik yang digunakan untuk menganalisis data dengan cara mendeskripsikan atau menggambarkan data yang telah terkumpul, serta disajikan dalam bentuk tabel, grafik, diagram, perhitungan rata-rata, standar deviasi dan perhitungan persentase.

\section{HASIL}

Sebelum melakukan perhitungan menggunakan persentase, terlebih dahulu akan mencari perhitungan rata-rata skor kelompok terlebih dahulu untuk mendistribusikan data yang digunakan dengan berdasarkan 3 kategori sebagaimana ditampilkan pada Tabel 1 sebagai berikut :

Tabel 1. Hasil Pesentase Kategori Stress Akademik Mahasiswa

\begin{tabular}{cccccc}
\hline & $\begin{array}{c}\text { Mahasiswa BK } \\
\text { Kelas }\end{array}$ & \multicolumn{4}{c}{ Mahasiswa BK Kelas Palembang dan Indralaya } \\
\cline { 3 - 6 } Komponen & $\begin{array}{c}\text { Palembang dan } \\
\text { Indralaya }\end{array}$ & Kognitif & Afektif & Fisiologis & Perilaku \\
\hline Skor Tertinggi & 270 & 120 & 68 & 48 & 49 \\
Skor Terendah & 113 & 47 & 35 & 16 & 15 \\
Skor Rata-rata & 21.60 & 89.44 & 55.45 & 34.01 & 37.11 \\
Standar Deviasi & 32 & 15.08 & 7.93 & 6.51 & 6.44 \\
Varian & 10.21 & 22.72 & 62.94 & 42.42 & 41.49 \\
\hline
\end{tabular}

Tabel 1 menunjukkan bahwa mayoritas mahasiswa program studi bimbingan dan konseling mengalami stress akademik dalam kategori sedang, untuk lebih jelas dapat dilihat pada gambar berikut: 


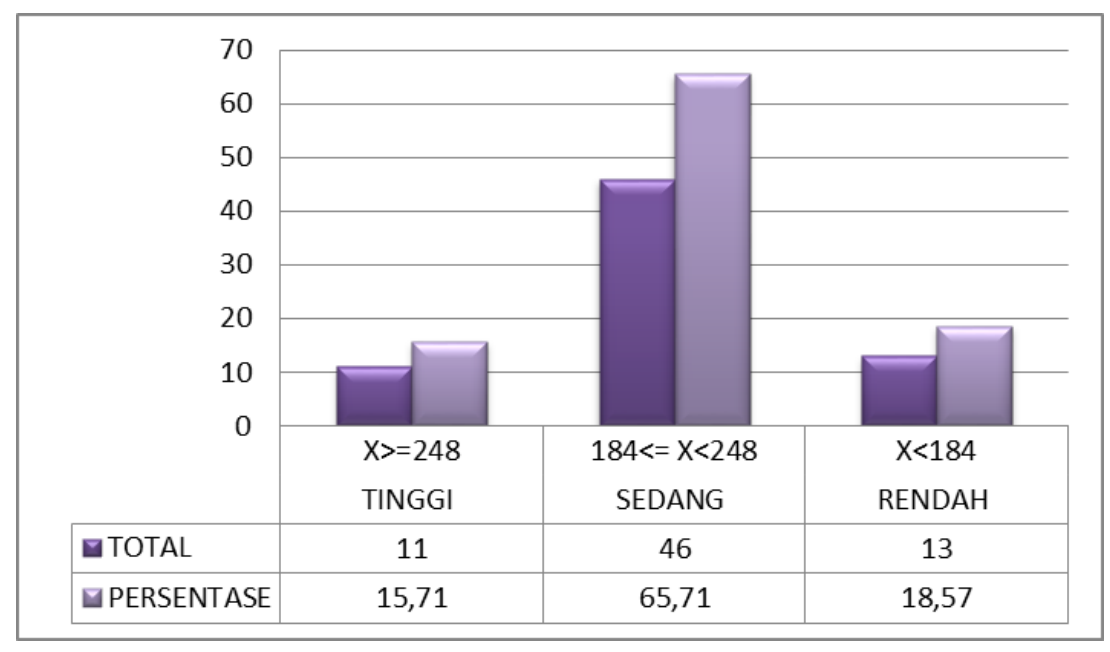

Gambar 1 Grafik Kategori Stress Akademik Mahasiswa

Gambar 1 menunjukkan bahwa keseluruhan bahwa Mahasiswa Bimbingan dan Konseling kelas Palembang-Indralaya angkatan 2018, 2019, 2020 termasuk dalam kategori sress akademik sedang; dengan jumlah 46 mahasiswa $(65,71 \%)$. Temuan ini menunjukkan bahwa pada tingkat stress akademik dengan kategori sedang perlu dilakukan antisipasi. Menurut Psychology Foundation of Australia pada kondisi stress akademik dengan kategori sedang mahasiswa cenderung akan menjadi mudah marah, dan tidak fokus sehingga dapat mempengaruhi kemampuan dan orientasi terhadap kegiatan proses pembelajaran yang diikuti oleh Mahasiswa (Humphrey, 2003).

\section{Pembahasan}

Mahasiswa akan menjadi pusing dan melakukan penundaan penyelesaian tugas dan mengalami gangguan pada pola tidur, (Yuwono, 2020b). Selain itu juga stressor sedang akan menimbulkan gejala seperti mudah marah, bereaksi secara berlebihan terhadap suatu situasi, sulit untuk beristirahat, merasa lelah dan cemas, mudah tersinggung dan gelisah (Humphrey, 2003). Mahasiswa yang termasuk kategori sedang ini menunjukkan bahwa individu akan mengalami kondisi yang lebih fokus terhadap hal-hal yang tidak penting dan mengesampingkan hal yang akan dapat mempersempit lahan persepsinya (Muhaimin, 2018:8). Namun kemungkinan stress sedang ini akan berubah menjadi stress tinggi apabila individu tidak dapat mengelola dan mangatur dirinya dengan baik selama proses pembelajaran daring. Stress akademik sedang dengan jumlah banyak atau terjadi secara terus-menerus akan meningkatkan resiko penyakit pada Mahasiswa.

Berdasarkan dari data yang didapatkan yakni sebanyak 11 orang mahasiswa Bimbingan dan Konseling kelas Palembang-Indralaya angkatan 2018, 2019, 2020 yang termasuk dalam kategori tinggi dengan persentase $15,71 \%$ yang mana menunjukkan bahwa mahasiswa memiliki kecenderungan kurang baik dalam mengelola dan mengontol emosi selama pembelajaran daring, memiliki kemampuan yang rendah. Pada mahasiswa yang terkategori mengalami stress akademik yang tinggi ini juga, individu memiliki kemampuan yang sangat menurun dan memiliki kecenderungan dalam memusatkan perhatian pada hal lain yang bukan berkaitan dengan pembelajaran. Dan hal ini juga menunjukkan bahwa tingkat stress tinggi maupun sedang dapat menghambat proses pembelajaran. Yang tentunya akan

Stress ringan atau rendah ini tidak membahayakan, justru sebaliknya diperlukan untuk meningkatkan kualitas diri dan prestasi belajar. Seseorang yang menilai suatu stress sebagai 
tantangan (Challenge) tentu akan memiliki semangat yang tinggi, dikarenakan merasa tertantang berarti merasa positif terhadap tuntutan yang sedang dihadapi.

Aspek stress akademik selama pembelajaran daring pada Mahasiswa Bimbingan dan Konseling kelas Palembang-Indralaya angkatan 2018, 2019, 2020 selama Pandemi COVID19 menunjukkan bahwa Mahasiswa berada pada aspek kognitif dengan persentase 65,71 atau 46 Mahasiswa pada kategori sedang. Yang mana stress akademik mahasiswa dipengaruhi oleh salah satu aspek kognitif pada indikator yang memiliki persentase lebih tinggi dari indikator aspek kognitif lainnya yakni mengalami kebingungan dengan persentase yakni 21,93\%. Yang artinya dalam Hal ini menunjukkan bahwa pemicu terjadinya stress akademik pada mahasiswa bimbingan dan konseling kelas Palembang-Indralaya yakni disebabkan oleh ratarata mahasiswa mengalami kebingungan selama pembelajaran daring. Terjadinya keterlambatan kegiatan akademik berhubungan positif dengan adanya kebingungan selama pembelajaran daring dimasa pandemi COVID-19.

\section{SIMPULAN}

Studi ini menyimpulkan bahwa mahasiswa Bimbingan dan Konseling Kelas Palembang-Indralaya angkatan 2018, 2019, 2020 mengalami stress akademik dengan kategori sedang. Penyebab mahasiswa mengalami stress akademik dengan kategori sedang ini yakni yang pertama dominan dipengaruhi oleh aspek kognitif yaitu mahasiswa mengalami kebingungan selama pembelajaran daring, yang kedua dominan dipengaruhi oleh aspek afektif dengan kategori sedang hal ini menyatakan bahwa mahasiswa memiliki kemampuan diri yang buruk terhadap tuntutan akademik, yang ketiga dominan dipengaruhi oleh aspek Fisiologis dengan kategori sedang yakni mengalami kesulitan untuk tidur, dan yang dominan terakhir yakni dipengaruhi oleh aspek perilaku dengan kategori sedang melakukan penundaan pekerjaan terhadap tuntutan akademik selama pembelajaran daring di masa pandemi Covid19.

\section{UCAPAN TERIMA KASIH}

Para penulis mengucapkan terima kasih atas kesempatan dan kesediaan waktu serta kepercayaan yang diberikan oleh Universitas Sriwijaya terutama Program Studi Bimbingan dan Konseling untuk memberikan kesempatan kepada kami untuk melaksanakan penelitian ini.

\section{References}

Agustiningsih, N. (2019). Gambaran Stress Akademik dan Strategi Koping Pada Mahasiswa Keperawatan. Jurnal Ners Dan Kebidanan (Journal of Ners and Midwifery), 6(2), 241-250. https://doi.org/10.26699/jnk.v6i2.art.p241-250

Anugrahana, A. (2020). Hambatan, Solusi dan Harapan: Pembelajaran Daring Selama Masa Pandemi Covid-19 Oleh Guru Sekolah Dasar. Scholaria: Jurnal Pendidikan Dan Kebudayaan, 10(3), 282-289. https://doi.org/10.24246/j.js.2020.v10.i3.p282-289

Barseli, M., Ifdil, I., \& Fitria, L. (2020). Stress akademik akibat Covid-19. Jurnal Penelitian Guru Indonesia, 5(2), 95-99.

Boyraz, G., \& Legros, D. N. (2020). Coronavirus Disease (COVID-19) and Traumatic Stress:

Probable Risk Factors and Correlates of Posttraumatic Stress Disorder. Journal of Loss and

Trauma, 25(6-7), 503-522. https://doi.org/10.1080/15325024.2020.1763556 
Fauzi, A., Psikologi, P. S., Kedokteran, F., Mangkurat, U. L., \& Km, J. A. Y. (2020). Tingkat Stress Mahasiswa Dengan Tugas Yang Diberikan. Https://Psyarxiv.Com/T3K97/, 1-7. https://psyarxiv.com/t3k97/

Harahap, A. C. P., Harahap, D. P., \& Harahap, S. R. (2020). Analisis Tingkat Stres Akademik Pada Mahasiswa Selama Pembelajaran Jarak Jauh Dimasa Covid-19. Biblio Couns : Jurnal Kajian Konseling Dan Pendidikan, 3(1), 10-14. https://doi.org/10.30596/bibliocouns.v3i1.4804

Hasanah, U., Ludiana, Immawati, \& PH, L. (2020). Gambaran psikologis mahasiswa dalam proses pembelajaran selama pandemi Covid-19. Jurnal Keperawatan Jiwa, 8(3), 299-306. https://jurnal.unimus.ac.id/index.php/JKJ/article/view/5941

Humphrey, J. H. (2003). Stress Education for College Students. New York: Novinka Books.

Hutagalung, R. (2019). Tingkat Stres Akademik Mahasiswa Tingkat I Diploma III Keperawatan di Sekolah Tinggi Ilmu Kesehatan Dirgahayu Samarinda. Jurnal Keperawatan Dirgahayu, 1(2).

Hurlock. (2003). Psikologi Perkembangan. Jakarta: Erlangga.

Ifdil, T., \& Ardi, Z. (2013). Kondisi Stres Akademik Siswa SMA Negeri di Kota Padang. Jurnal Konseling Dan Pendidikan, 1, 143-150.

Indrayana, B., \& Sadikin, A. (2020). Ilmiah 2020. Indonesion Journal of Sport Science and Coaching, O(1), 46-55. https://online-journal.unja.ac.id/IJSSC/article/view/9847

Jam, F. A., Khan, T. I., Zaidi, B. H., \& Muzaffar, S. M. (2011). Political skills moderates the relationship between perception of organizational politics and job outcomes. Journal of Educational and Social Reseacrh, 1(4), 57-70.

Kountul, Y. P. D., Kolibu, F. K., Korompis, G. E. C., Kesehatan, F., Universitas, M., Ratulangi, S., \& Sebaya, P. T. (2019). Faktor-Faktor Yang Berhubungan Dengan Tingkat Stres Pada Mahasiswa Fakultas Kesehatan Masyarakat Universitas Sam Ratulangi Manado. Kesmas, 7(5).

Moh, M. (2020). Moh . Muslim: Manajemen Stress pada Masa Pandemi Covid-19" 193. Jurnal Manajemen Bisnis, 23(2), 192-201.

Pawicara, R., \& Conilie, M. (2020). Analisis Pembelajaran Daring Terhadap Kejenuhan Belajar Mahasiswa Tadris Biologi Iain Jember di Tengah Pandemi Covid-19. ALVEOLI: Jurnal Pendidikan Biologi, 1(1), 29-38.

Rosali, E. S. (2020). Aktifitas Pembelajaran Daring Pada Masa Pandemi Covid -19 Di. Geography Science Education Journal (GEOSEE), 1(1), 21-30. https://www.researchgate.net/publication/340917125_Kendala_Pelaksanaan_Pembelajaran_Jarak _Jauh_PJJ_dalam_Masa_Pandemi/stats

Sadikin, A., \& Hamidah, A. (2020). Pembelajaran Daring di Tengah Wabah Covid-19. Biodik, 6(2), 109-119. https://doi.org/10.22437/bio.v6i2.9759

Sagita, D. D., Daharnis, D., \& Syahniar, S. (2017). Hubungan Self Efficacy, Motivasi Berprestasi, Prokrastinasi Akademik Dan Stres Akademik Mahasiswa. Bikotetik (Bimbingan Dan Konseling: Teori Dan Praktik), 1(2), 43. https://doi.org/10.26740/bikotetik.v1n2.p43-52

Sekar, S., Ananda, D., \& Apsari, N. C. (2020). Mengatasi Stress Pada Remaja Saat Pandemi Covid19. 7(2), 248-256.

Soto-Rubio, A., Giménez-Espert, M. D. C., \& Prado-Gascó, V. (2020). Effect of emotional intelligence and psychosocial risks on burnout, job satisfaction, and nurses' health during the covid-19 pandemic. International Journal of Environmental Research and Public Health, 17(21), 1-14. https://doi.org/10.3390/ijerph17217998

Sugiyono. (2014). Metode Penelitian Pendidikan Pendekatan Kuantitatif, Kualitatif, dan $R \& D$. Bandung: Alfabeta.

Syah, M. (2010). Psikologi Belajar. Bandung: PT. Remaja Rosdakarya.

Yuwono, S. D. (2020a). Profil Kondisi Stres Di Masa Pandemi Covid-19 Sebagai Dasar Intervensi Dalam Praktek Mikrokonseling. Ristekdik: Jurnal Bimbingan Dan Konseling, 5(1), 132-138.

Yuwono, S. D. (2020b). Profil Kondisi Stres Di Masa Pandemi Covid-19 Sebagai Dasar Intervensi Dalam Praktek Mikrokonseling. Ristekdik: Jurnal Bimbingan Dan Konseling, 5(1), 132-138.

Journal of Learning and Instructional Studies (2021), 1(1), 17-24

https://doi.org/10.46637/jlis.v1i1.3 